\title{
Sero-prevalence of bovine leukemia virus in cattle from Caquetá state, Colombia
}

\author{
Seroprevalencia del virus de la leucosis en bovinos del departamento \\ del Caquetá, Colombia
}

Motta-Delgado P, Rivera-Calderón L, Herrera-Valencia W, Martínez-Tovar R, Londoño-Sánchez M, Rojas-Vargas E, et al. Sero-prevalence of bovine Leukemia virus in cattle from Caquetá state, Colombia. Rev Colombiana Cienc Anim. Recia. 2019; 11(2):Articulo722. DOI: https://doi. org/10.24188/recia.v11.n1.2019.722

Universidad de Sucre, Colombia

Los autores permiten a RECIA reimprimir el material publicado en él. En caso de que un autor quiera traducir o usar una publicación parcial o completa de nuestro Diario, el autor debe obtener un permiso por escrito del editor de la revista.

Revista Colombiana de Ciencia Animal - RECIA está distribuido bajo una Licencia Creative Commons Atribución-CompartirIgual 4.0 Internacional. 


\title{
Sero-prevalence of bovine leukemia virus in cattle from Caquetá state, Colombia
}

\author{
Seroprevalencia del virus de la leucosis en bovinos del departamento del Caquetá, Colombia
}

Pablo Andrés Motta-Delgado* M.Sc.

DOI: https://doi.org/10.24188/recia.v11.n2.2019.722

Misión Verde Amazonia Corporation. Florencia, Caquetá, Colombia

pmotta@misionverdeamazonia.org

D. https://orcid.org/0000-0001-8820-5542

Luis Gabriel Rivera-Calderón. Ph.D.

Antonio Nariño University. Popayán, Cauca, Colombia

lgriveramvz@gmail.com

(D) https://orcid.org/0000-0003-4455-8404

Wilmer Herrera-Valencia. M.Sc.

Misión Verde Amazonia Corporation. Florencia, Caquetá, Colombia

wilmerbr@yahoo.com.br

https://orcid.org/0000-0001-9263-8711

Ricardo Alberto Martínez-Tovar. M.Sc.

Misión Verde Amazonia Corporation. Florencia, Caquetá, Colombia

ramartineztov@gmail.com

(iv) https://orcid.org/0000-0001-5615-6715

Marliyanini Londoño-Sánchez. B.Sc.

Misión Verde Amazonia Corporation. Florencia, Caquetá, Colombia

marlylondono2306@gmail.com

https://orcid.org/0000-0003-4454-7780

Erika Paola Rojas-Vargas. B.Sc.

Antonio Nariño University. Popayán, Cauca, Colombia

rojasvargasmva@gmail.com

D http://orcid.org/0000-0003-4654-9368

Angie Liseth Muñoz-Murcia. Z.V.D.

Misión Verde Amazonia Corporation. Florencia, Caquetá, Colombia aenegeie-ansas@hotmail.com

iD https://orcid.org/0000-0003-1777-016X

María Elodia Gutiérrez-Quintero. Z.V.D., Sp.

Colombian Agricultural Institute, Veterinary Diagnostics Laboratory.

Florencia, Caquetá, Colombia

Recepción: 26 Abril 2019

maria.gutierrez@ica.gov.co

(iD) https://orcid.org/0000-0001-8553-2951

\begin{abstract}
Bovine Leukemia Virus (BLV) is the agent of enzootic bovine leukosis (EBL), this disease is a neoplasm of lymphatic tissues in bovine species. The aim of this article was determinate the prevalence of bovine leukemia virus in dual-purpose cattle from nine municipalities that carrying the $75 \%$ of bovine population in the Caquetá state, Colombia. Blood samples were collected in 100 herds dedicates to dual purpose cattle, obtained blood serum from 1000 animals, of which 893 corresponding to cows. Indirect Elisa test for detection of antibodies anti-GP51 of BLV was performance and the positive cases were considered if the serum-to-positive ratio with percentages of $\mathrm{M} / \mathrm{N}$ lower than $40 \%$. Categorized data were analyzed by contingency tables and ANOVA at the significant level of $\mathrm{p}<0.05$ by DGC test was performed. The overall sero-prevalence of BLV in Caquetá state was of 25.18\% (95\%, CI: 21.9-28.46\%), in males 26.25\% and females 25.37\% respectively. At municipal level the sero-prevalence varied of 7.12 to $41.81 \%$. The prevalence of BLV at herd level was of $67 \%$ (95\%, CI: 57.24-76.76\%). In conclusion, the sero-prevalence of BLV in the dual-purpose livestock system over 36 months of age in Caquetá state is moderate, do not exist statistical difference between sero-prevalence of cows and bulls. At level of herds the prevalence of BLV is high. Improving strategies of control and managements in the herds, as well as implement policies of sanitary management are necessary.
\end{abstract}

Keywords: Amazon region, Deltaretrovirus, epidemiology, immunosuppressive agent, lymphocytosis, lymphoma, tropical zone (MeSH and DeCS) 


\section{RESUMEN}

El virus de la leucosis bovina (VLB) es el agente de la leucosis enzoótica bovina (LEB), una neoplasia en tejidos linfáticos de la especie bovina. El objetivo del presente artículo fue determinar la prevalencia del virus de la leucosis bovina en ganado doble propósito mayor a 36 meses en nueve municipios que sostienen el $75 \%$ de la población bovina en el departamento del Caquetá, Colombia. En nueve municipios fueron colectadas muestras de sangre en 100 predios ganaderos dedicados al sistema de doble propósito, obteniendo suero sanguíneo de 1000 animales, de los cuáles 893 correspondieron a vacas. Se realizó la prueba Elisa indirecta para detección de anticuerpos anti GP51 para VLB considerando casos positivos con porcentajes de $\mathrm{M} / \mathrm{N}$ menor a 40\%. Los datos categorizados fueron analizados por tablas de contingencia y fue desarrollada ANAVA por prueba DGC a un nivel de significancia de $p<0,05$. Se obtuvo una seroprevalencia general de $25,18 \%(p<0,05$, IC: $21,9-28,46 \%$ ) en el departamento del Caquetá, 26,25\% en machos y de 25,37\% en hembras respectivamente. A nivel municipal la seroprevalencia varió desde el $7.12 \%$ hasta el 41,81\%. La prevalencia de VLB a nivel de predios fue del $67 \%$ (p<0,05, IC: 57,24-76,76\%). En conclusión, la seroprevalencia de VLB in ganado doble propósito mayor a 36 meses es moderado, no existiendo diferencia entre la prevalencia en toros y vacas. A nivel de hatos la prevalencia fue alta. Es necesario mejorar las estrategias de manejo y control de hatos, así como aplicar políticas de manejo sanitario.

Palabras clave: Amazonia, agente inmunosupresor, Deltaretrovirus, epidemiologia, linfocitosis, linfoma, zona tropical (MeSH and DeCS)

\section{INTRODUCTION}

Bovine Leukemia Virus (BLV) is the agent of enzootic bovine leukosis (EBL), a neoplasm of lymphatic tissues in bovine species $(1,2,3,4)$, BLV is classified into the genus Deltaretrovirus in the family Retroviriadae (3). EBL is characterized by three disease stages: asymptomatic or aleukemic (AL), persistent lymphocytosis (PL), and leukemia or lymphoma (5). The majority of infected animals remain healthy without apparent negative economic effects, but BLV carriers develop a form of the disease known as persistent lymphocytosis (PL) in 30\% of infected animals, while $0.1-10 \%$ of BLV-infected animals will develop either leukemia or lymphoid tumors $(1,3,6,7)$.

During BLV infection, reduced cellular immune responses play major roles in disease progression and lead to increased susceptibility to other infections $(6,7,8)$, BLV reduces anti-viral cytokine activities by suppression of interferongamma (IFN-g) and Tumor Necrosis Factor (TNF-a), and natural killer (NK) cytotoxicity by inducing transforming growth factor (TGF)- $\beta$ secretion from regulatory T cells, suggesting that TGF- $\beta$ from T cells type CD $4^{+} C D 25^{\text {high }}$ Foxp $3^{+}$is immunosuppressive and contribute to diseases progression (9).

Iatrogenic infection through blood-contaminated needles, surgical instruments, and gloves for rectal palpation is probably the major route of transmission in most settings $(10,11)$. Field transmission of BLV requires direct prolonged contact between animals or exchange of blood, exudates, or tissues (e.g. during parturition), the spread of BLV between herds can occur via infected animals, while semen, or hematophagous insects probably account for an only small proportion of cases (10). Infection of BLV, according to detected by serology, is more typical in older cattle than the younger cattle (12).

EBL occurs worldwide in cattle-raising countries. In most of these countries, EBL is a notifiable disease, and official control measures include screening or monitoring, precautions at borders, control of movement inside the country, and stamping out (10). EBL has been eradicated in 22 countries worldwide through national control program, in many European countries in recent years their cattle population is relatively free from BLV $(5,13,14)$.

In fact, for the Caquetá state, only a study about prevalence of EBL has been developed by (15) more than 15 years ago, and a new study for to determinate and to upgrade the prevalence of BLV is necessary taking into account that the bovine population in this state is amounts of 1,686,852 animals, and this state is the fifth dairy basin more important of Colombia, with a milk production higher to $1.215 .833 \mathrm{~kg}$ per day(16).

The aim of this research was determinate the prevalence of bovine leukemia virus in dual-purpose cattle over 36 months of age, in the nine municipalities that carrying the $75 \%$ of bovine population in the Caquetá state.

\section{MATERIALS AND METHODS}

Area of study. The research was performed in nine municipalities from Caquetá State, located to south of Colombia and the northeast of the Colombian Amazonia, between the $00^{\circ} 42^{\prime} 17^{\prime \prime}$ of latitude south and $02^{\circ} 04^{\prime} 13^{\prime \prime}$ of latitude north, and the $74^{\circ} 18^{\prime} 39^{\prime \prime}$ and $79^{\circ} 19^{\prime} 35^{\prime \prime}$ of longitude west of Greenwich. Borders to the North with both Meta and Guaviare states, to east with both Vaupes and Amazonas states, to south with the Putumayo and the west with both Cauca and Huila states; the Caquetá state have an extension of $88,965 \mathrm{~km}^{2}$ and is politically divided in 16 municipalities (17). The municipalities involved in the study were: Albania, San José del Fragua, La Montañita, Milán, El Paujil, El Doncello, Cartagena del Chairá, Puerto Rico and San Vicente del Caguán.

Caquetá state has three thermal floors (cold, temperate and warm). In warm climate that covers the greatest area to state, the average precipitation is of $3.800 \mathrm{~mm} /$ year, without dry station well defined, (nevertheless, the lower precipitation is registered between December to January and the greater precipitation between March to November), the rainfall erosivity index $\left(\mathrm{R}_{\text {or }} \mathrm{EI}_{30}\right.$ ) multiannual is the $2.750 \mathrm{tm} / \mathrm{cm} / \mathrm{ha} / \mathrm{h}$, value three times greater than other regions of country, the relative humidity is greater than $80 \%$, but can fluctuate between 64 to $93 \%$, with temperatures range between 18 to 
$36^{\circ} \mathrm{C}$ with average annual of $25^{\circ} \mathrm{C}$ characteristic of a regime isohyperthermic. The evapotranspiration potential is 1.435 $\mathrm{L} / \mathrm{m}^{2} /$ year, the average of solar radiation is of 1.800 hours/year and the intensity of $268 \mathrm{cal} / \mathrm{m}^{2} / \mathrm{day}(18,19,20) . \mathrm{The}$ climatic characteristics in the study area are of tropical rainforest according to Holdridge Life Zone Ecology (21).

Methodological design. A transversal study for estimate the sero-prevalence of bovine leukemia virus in dual-purpose cattle in the Caquetá state was performed. The probability of success was determinate in a level of $50 \%$. A stratified random sampling of herds was made, taking into account herds dedicates to dual-purpose production, bovine females in milk production and bulls of each farm.

The sample size. Using the information of the agricultural assessment 2016 of the secretary of Agriculture of Caquetá state, the total of bovines females over 36 months of age were of 374317 . Was calculated the sample size from a known population, using the following equation:

$$
n=\frac{\left(N \times Z_{a}^{2} \times p \times q\right)}{\left[d^{2} \times(N-1)+Z_{a}^{2} \times p \times q\right]}
$$

Where $n$ = sample size, $N=$ population size $(374,317), Z=$ confidence level $(\mathrm{p}<0.05), p=$ probability of success $(0.5), q=$ probability of failure (0.5), and $d=$ precision (maximum allowable in terms of ratio error) (3.5\%). So, the sample size was estimated at 782 females over 36 months of age.

For estimation of sample size of dual-purpose herds the previous equation was used with the following assumptions: $N$ = population size (11.128), $Z=$ confidence level $(\mathrm{p}<0.05), p=$ probability of success $(0.5), q=$ probability of failure $(0.5)$, and $d=$ precision (maximum allowable in terms of ratio error) (10\%), thus was estimated a minimum sample size of 95 herds of dual-purpose.

Selection of herds. The herds were selected from the data base of project: "Implementación y validación de modelos alternativos de producción ganadera en el departamento del Caquetá" [Implementation and validation of alternative methods for cattle production in Caquetá state], taking into account the 500 herds of dual-purpose cattle distributed in nine municipalities of Caquetá state, and some criteria proposed (22) were used, but modified for this research, thus: a) the farm size (50-180 hectares), b) herds with more than 10 cows in milking (over 36 months of age), c) availability to cooperate in the project, and d) accessibility and roads in good conditions.

Ethics aspects. The samples were taken by Veterinarians and endorsed by the inspectors of the entity of inspection authorized by the Colombian Agricultural Institute (ICA by the acronyms in Spanish) in the Florencia branch, following the ethics, technical, scientific and administrative regulations for the research with animals, according to the law 84 of 1989 of Colombia. Throughout the research the confidentiality of farms positives to BLV was maintained. The project was approved by the resolution 005 of 2013 by the Science, Technology and Innovation Fund (FCTeI) of the National Planning Department (DNP) of Colombia with advice of Colciencias as technical secretariat.

Diagnosis. Between the months of January to March of 2016 blood serum sampling were carried out in 100 herds dedicated to the dual-purpose cattle system, in each were sampled ten bovines (nine cows and one bull) over 36 months of age for a total to 1.000 bovines.

Blood samples were obtained by venipuncture in the coccygeal vein, prior cleaning and disinfection of the area with ethyl alcohol at 70\% (23), the blood samples were deposited in sterile tubes without anticoagulant (red top) to ensure that the serum obtained, all samples were properly labeled the animal information: identification, sex, age, identification to herd and date of sampling.

Subsequently, the blood samples were stored in thermos conveyors maintaining refrigeration at $4-8^{\circ} \mathrm{C}$. All samples were sent to the laboratory of veterinary Diagnostics of the Colombian Agricultural Institute (ICA) in the Florencia city.

In the laboratory of Veterinary Clinical Diagnostics was conducted the tests established by the ICA for the diagnosis of bovine leukemia virus in Colombia, blood serum was obtained and was carried out with indirect Elisa test for detection of antibodies anti-GP51 of BLV (IDEXX) $(11,24)$. A bovine was considered positive to BLV if the serum-to-positive ratio was lower than $40 \%$, as recommended by the manufacturer of the kit (25).

Data were tabulated in Excel spreadsheet and subsequently analyzed by descriptive statistics using the statistical software InfoStat (26), contingency tables for analysis of categorized data were used, and also, ANOVA was performed with DGC test at 0.05 of significance level as multiple-comparison method (27).

\section{RESULTS}

In total were sampled 1000 bovines distributed in 100 herds of dual-purpose cattle, of which 893 blood serum corresponding to cows, 80 to Bulls and 27 to hemolyzed blood serum because they were hemolyzed in the transport.

Sero-prevalence of bovine leukemia virus in the Caquetá state was of the $25.18 \%$ (p<0.05, CI: 21.9-28.46), with the equal prevalence both in females as in males (Table 1). 
Table 1. Sero-prevalence of bovine leukemia virus (BLV) in the Caquetá State.

\begin{tabular}{ccccccc}
\hline \multirow{2}{*}{ Result } & \multicolumn{2}{c}{ Females } & \multicolumn{2}{c}{ Males } & \multicolumn{2}{c}{ Total } \\
\cline { 2 - 7 } & Cases & $\mathbf{\%}$ & Cases & \% & Cases & \% \\
\hline Negative & 669 & $75.76^{\mathrm{a}}$ & 59 & $73.75^{\mathrm{a}}$ & 728 & $74.82^{\mathrm{a}}$ \\
Positive & 224 & $25.37^{\mathrm{b}}$ & 21 & $26.25^{\mathrm{b}}$ & 245 & $25.18^{\mathrm{b}}$ \\
Total & $\mathbf{8 8 3}$ & $\mathbf{1 0 0}$ & $\mathbf{7 8}$ & $\mathbf{1 0 0}$ & $\mathbf{9 6 1}$ & $\mathbf{1 0 0}$ \\
\hline
\end{tabular}

Value with same letter does not have statistically significant $(\mathrm{p}<0.05)$.

Low sero-prevalence of BLV was found in La Montañita (7.12\%), San Vicente del Caguán (14.62\%), Albania (21.85\%), and Cartagena del Chairá (30.70\%) municipalities, and statistical difference in this four municipalities was not found; in the same way, higher sero-prevalence of BLV was found in Milán (30.70\%), El Paujil (33.10\%), El Doncello (38.92\%), San José del Fragua (38.92) and Puerto Rico (41.81\%) municipalities, these last five municipalities showed the statistical difference with the first four (Figure 1).

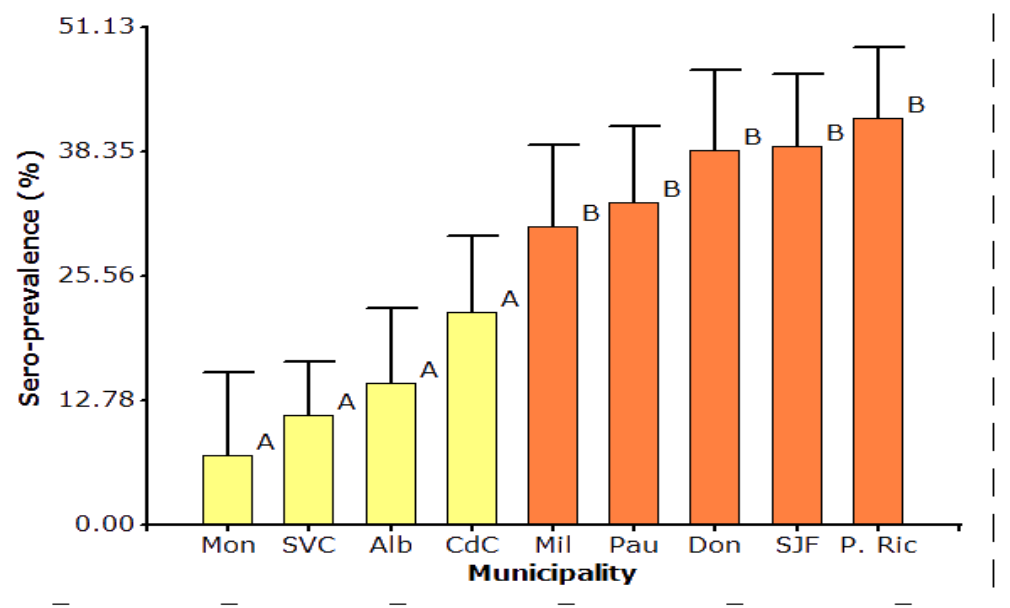

Figure 1. Sero-prevalence of bovine leukemia virus in nine municipalities of the Caquetá state. Mon: La Montañita, SVC: San Vicente del Caguán, Alb: Albania, CdC: Cartagena del Chairá, Mil: Milán,

Pau: El Paujil, Don: El Doncello, SJF: San José del Fragua and P. Ric: Puerto Rico.

At least one positive case for bovine leukemia virus was criteria for considering a positive herd, were meet in 67 herds of nine municipalities, thus the prevalence of disease at level of herd was of $67 \%$ ( $<<0.05$, CI: 57.24-76.76\%), (Table 2).

Table 2. Prevalence of bovine leukemia virus in herds of dual-purpose cattle in nine municipalities of Caquetá state.

\begin{tabular}{cccc}
\hline Municipality & Number of herds samples & Number of herds positives & Prevalence (\%) \\
\hline Albania & 10 & 7 & 70 \\
Cartagena del Chairá & 10 & 6 & 60 \\
El Doncello & 10 & 7 & 70 \\
El Paujil & 10 & 8 & 80 \\
La Montañita & 10 & 4 & 40 \\
Milán & 10 & 7 & 70 \\
Puerto Rico & 10 & 10 & 100 \\
San José del Fragua & 10 & 7 & 70 \\
San Vicente del Caguán & 20 & 11 & 55 \\
\hline TOTAL & $\mathbf{1 0 0}$ & $\mathbf{6 7}$ & $\mathbf{6 7}$ \\
\hline
\end{tabular}




\section{DISCUSSION}

In a study by cluster in Colombia (28), found a prevalence for BLV of $22.6 \%$, where dairy cattle was the most susceptible to the infection with $50.7 \%$, followed by the dual-purpose cattle with $14.9 \%$, results lower than this study.

In Colombia, has been reported sero-prevalence of BLV at municipal level, in the following states: Antioquia 44-47.8\% (25, 29), Boyacá 41.44\% (30), Caquetá 11.2\% (15), Casanare 15\% (31), Cesar 36\% (32), Córdoba 21\% (33), Cundinamarca $26-64 \%(34,35)$, Nariño $19.8 \%$ (36), Valle del Cauca $30.3-77.83 \%(24,37)$, Santander $73.3 \%(38)$ and the region of the Magdalena Medio 64.94\% (39). In this sense, the report of BLV in Colombia varied between 11.2 to $77.83 \%$, therefore, the prevalence of the disease in Caquetá state (25.18) is between national ranges, nevertheless, it is greater to the prevalence in Casanare, Córdoba, and Nariño, but lower than the others states.

For South America various studies have been performed. In the Barinas state of Venezuela, (23), found a sero-prevalence of $60.83 \%$ of BLV, also in Argentina for the year 1999 the sero-prevalence of infected animals with BLV was of 32.85\% (40) and for the 2007 seroprevalence was of 77.4\% (41), likewise, in Perú, Chile and Bolivia seroprevalence level was of 42.3, 27.9 and $30.7 \%$ respectively Polat et al (41) reports were higher than this study. However, in a research in Brazil a sero-prevalence of $11.7 \%$ were found (42), being lower than this study.

Worldwide the prevalence of BLV is varied, in studies performed in Asia the prevalence of BLV is higher than this research, for example, in the prefecture of Osaka, Japan, a total of 774 dairy cows over 48 months of age were sampled and the prevalence of BLV was of 60.33\% (43), other study in nine provinces of Thailand (44), found a seroprevalence of BLV between 11.0 to $100 \%$. But in a study in four provinces of Cambodia sero-prevalence of the BLV was between 0 to $16.8 \%$ (45) and, in four township of Myanmar a prevalence of 9.1\% was found (46), being both lower than this research. Nevertheless, in Europe the prevalence is lower than this research, for Italy (47), reported an animal sero-prevalence of 0.015\%. In Finland (10), for the year 2001 reported a prevalence of BLV of 0\%, and for Portugal until the year 2005 a seroprevalence was of $0.036 \%$ (48). For Africa the epidemiological situation is not better, in a study performed in Namibia, a sero-prevalence of BLV was of $12.3 \%$, but varied of 0 to $52.6 \%$ at level of districts (49); in six regions of Tanzania a study found a seroprevalence of BLV of 36\% (50), contrarily, in two districts of Somalia the sero-prevalence was of $1.5 \%$ (51), and other in a province of South Africa was of $12.6 \%$ (52), being lower than this study.

Moreover, the presence of BLV depends on the breed, being low in animals of Brahman breed (53), but high in Holstein (40), found that in sero-positive cows to BLV the calving interval is higher than sero-negatives cows. In the same sense, a study performed in Michigan state determinate that an increased prevalence of BLV is associated with decreased herd milk production and decreased cow longevity (56).

At level of herd (57), in the IX region of Chile, found in 279 herds a prevalence of BLV of 59\%. In the Mar and Sierra, Argentina, a prevalence was of $68.5 \%$ in dairy farms (58). A study developed in Japan found a prevalence of BLV of $44.8 \%$ (45). Other study in five prefectures of Japan showed a sero-prevalence at level of herds between 47 to $61 \%$ (2). In Argentina the prevalence in herd was of 84\% (43).On the contrary, in Italy the prevalence in herds was of $0.08 \%$ (49). In Iran, prevalence in farms was of $43.9 \%$ (59).

Although it is not clear the capacity of the BLV infect the human through the consumption of products derived from BLVpositive animals, antibodies against BLV have been found in humans, rethinking the hypothesis of a possible zoonosis; indeed, in patients with canicular carcinoma (breast cancer) was found a presence of $7 \%$ for protein gp51 of BLV suggesting presence in this pathology (60).

In conclusions the seroprevalence of Bovine Leukemia Virus (BLV) in the dual-purpose livestock over 36 months of age in Caquetá state is moderate with $25.18 \%$, do not exist statistical difference between seroprevalence of cows and bulls. At level of herds the prevalence of BLV is high with 67\%. Improving strategies of control and managements in the herds, as well as implement policies of sanitary management are necessary.

\section{Conflict of interest}

The authors expressed that conflict of interest in this publication there is no.

\section{Acknowledgments}

The authors are grateful to the Governorship of Caquetá state as executor of the resources of the project BPIN 2013000100164, which is financed by the Science Technology and Innovation Founding (FCTeI), form the Sistema General de Regalías, Colombia (SGR) and the team of Misión Verde Amazonia Corporation (http://misionverdeamazonia.org/) by enabling the development of this research. 


\section{REFERENCES}

1. Kettmann R, Burny A, Callebaut I, Droogmans L, Mammerickx M, Willems L, et al. Bovine leukemia virus. In Levy J. The Retroviridae. New York: Plenum Press; 1994.

2. Tsutsui T, Kobayashi S, Hayama Y, Nishiguchi A, Kameyama K, Konishi M, et al. Estimation of the within-herd transmission parameter of bovine leukemia virus. Prev Vet Med. 2010; 95(1-2):158-162. doi: http://dx.doi. org/10.1016/j.prevetmed.2010.02.008

3. Murakami K, Kobayashi S, Konishi M, Kemeyama K, Yamamoto T, Tsuitsui T. The recent prevalence of bovine leukemia virus (BLV) infection among Japanese cattle. Vet Microbiol. 2011; 148(1):84-88. doi: http://dx.doi. org/10.1016/j.vetmic.2010.08.001

4. Tsutsui T, Kobayashi S, Hayama Y, Yamamoto T. Fraction of bovine leukemia virus-infected dairy cattle developing enzootic bovineleukosis. Prev VetMed.2016;124:96-101.doi: http://dx.doi.org/10.1016/j.prevetmed.2015.11.019

5. Bartlett PC, Sordillo LM, Byrem TM, Norby B, Grooms DL, Swenson CL, et al. Options for the control of bovine leukemia virus in dairy cattle. J Am Vet Med Assoc. 2014; 244(8):914-922. doi: http://dx.doi.org/10.2460/ javma.244.8.914

6. Kabeya H, Ohashi K, Onuma M. Host immune responses in the course of bovine leukemia virus infection. J Vet Med Sci. 2001; 63(7):703-708. URL available in: https://www.ncbi.nlm.nih.gov/pubmed/11503896

7. Frie MC, Coussens PM. Bovine leukemia virus: a major silent threat to proper immune responses in cattle. Vet Immunol Immunopathol. 2015; 163(3-4):103-114. doi: http://dx.doi.org/10.1016/j.vetimm.2014.11.014

8. Gillet N, Florins A, Boxus M, Burteau C, Nigro A, Vandermeers F, et al. Mechanisms of leukemogenesis induced by bovine leukemia virus: prospects for novel anti-retroviral therapies in human. Retrovirology. 2007; 4:18. doi: http://dx.doi.org/10.1186/1742-4690-4-18

9. Kosuke O, Nakahara A, Konnai S, Okagawa T, Nishimori A, Maekawa N, et al. Bovine leukemia virus reduces antiviral cytokine activities and NK cytotoxicity by inducing TGF-b secretion from regulatory T cells. Immun Inflamm Dis. 2016; 4(1):52-63. doi: http://dx.doi.org/10.1002/iid3.93

10. Nuotio L, Rusanen H, Sihvonen L, Neuvonen E. Eradication of enzootic bovine leukosis from Finland. Prev Vet Med. 2003; 59(1-2):43-49. doi: http://dx.doi.org/10.1016/S0167-5877(03)00057-6

11. OIE. Manual of Standards for Diagnostic Tests and Vaccines. In OIE. Bovine Enzootic Leukosis. Paris: OIE - World Organization for Animal Health; 2016. URL available in: http://www.oie.int/fileadmin/Home/eng/Health standards/tahm/3.04.09 EBL.pdf

12. Erskine RJ, Bartlett PC, Byrem TM, Render CL, Febvay C, Houseman JT. Using a herd profile to determine agespecific prevalence of bovine leukemia virus in Michigan dairy herds. Vet Med Int. 2012; Article ID 350374, 5 pages. doi: http://dx.doi.org/10.1155/2012/350374

13. Acaite J, Tamosiunas V, Lukauskas K, Milius J, Pieskus J. The eradication experience of enzootic bovine leukosis from Lithuania. Prev Vet Med - Journal. 2007; 82(1-2):83-89. doi: http://dx.doi.org/10.1016/j.prevetmed.2007.05.010

14. Rodríguez SM, Florins A, Gillet N, de Brogniez A, Sánchez-Alcaraz MT, Boxus M, et al. Preventive and therapeutic strategies for bovine leukemia virus: lessons for HTLV. Viruses. 2011; 3(7):1210-1248. doi: http://dx.doi. org/10.3390/v3071210

15. Rodriguez JG, Ocaña HE, Vargas M. Determination of infectious diseases in dual purpose farms in the Balcanes Village, Florencia, Caquetá. Revista Facultad de Ciencias Agropecuarias. 2010; 2(2): 35-42. URL available in: https://www.udla.edu.co/revistas/index.php/ciencias-agropecuarias/article/download/386/383

16. Beltrán-Barreiro Y, Torrijos RR. Linea base de la industria láctea del Caquetá. Florencia:Comité de Ganaderos del Caquetá; 2013. https://es.scribd.com/document/259530628/Linea-Base-de-la-Industria-Lactea-del-Caquetapastos-y-forrajes-pdf

17. Gobernación del Caquetá. Plan de desarrollo 2012-2015: Gobierno de oportunidades Florencia, Caquetá: Gobernación de Caquetá; 2012. URL availaible in: http://cdim.esap.edu.co/BancoMedios/Documentos\%20PDF/ caquetaplandedesarrollo2012-2015.pdf

18. Escobar, ACJ, Zuluaga, PJJ, Rivera, DE. Aspectos de los suelos del departamento del Caquetá con relación al uso y manejo. Florencia: Corporación Colombiana de Investigación Agropecuaria (Corpoica); 1998. URL availaible in: http://bibliotecadigital.agronet.gov.co/handle/11348/6669

19. García J, Cipagauta M, Gómez J, Gutierrez A. Descripción, espacialización y dinámica de los sistemas de producción agropecuaria en el área intervenida del departamento de Caquetá Florencia, Caquetá: Corporación Colombiana de Investigación Agropecuaria (Corpoica); 2002. URL available in: http://hdl.handle.net/20.500.12324/12832 
20. Motta-Delgado, PA, Ocaña-Martínez, HE. Caracterización de subsistemas de pasturas en hatos de trópico húmedo, Caquetá, Colombia. Ciencia y Agricultura. 2018; 15(1): 81-92. Doi: https://doi.org/10.19053/01228420.v15. $\underline{\text { n1.2018.7759 }}$

21. Holdridge LR. Life zone ecology. Quinta reimpresión ed. San José: IICA (Instituto Interamericano de Cooperación para la Agricultura); 1978. URL availaible in: $\underline{\text { ttps://books.google.com.co/books?isbn=9290391316 }}$

22. Yamamoto W, Dewi IA, Ibrahim M. Effects of silvopastoral areas on milk production at dual-purpose cattle farms ar the semi-humid old agricultural frontier in central Nicaragua. Agric Syst. 2007; 94(2): 368-375. doi: http://dx.doi. org/10.1016/j.agsy.2006.10.011

23. Nava Z, Obando C, Molina M, Bracamonte M, Tkachuk O. Seroprevalence of Enzootic Bovine Leukosis and its Association with Clinical Signs and Risk Factors in Dairy Herds from Barinas State, Venezuela. Revista Facultad de Ciencias Veterinarias. 2011; 52(1):13-23. http://saber.ucv.ve/ojs/index.php/revisfcv/article/download/755/699

24. Hernandez DM, Álvarez L. Dynamics of bovine leukosis in creole cattle Hartón del Valle in natural infection. Archivos de Zootecnia. 2016; 65(251):365-373. URL available in: http://www.uco.es/ucopress/az/index.php/az/article/ view/698/662

25. Ramírez-Vasquez NF, Villar-Argaiz D, Fernandez-Silva JA, Londoño-Pino J, Chaparro-Gutiérrez JJ, Olivera-Ángel ME. Seroprevalence and risk factors of several bovine viral diseases in dairy farms of San Pedro de los Milagros, Antioquia, Colombia. Revista CES Medicina Veterinaria y Zootecnia. 2016; 11(1): 15-25. doi: http://dx.doi. org/10.21615/cesmvz.11.1.2

26. Di Rienzo JA, Casanoves F, Balzarini MG, González L, Tablada M, Robledo CW. Infostat versión 2017. Universidad Nacional de Córdoba: Argentina; 2017. https://www.infostat.com.ar/

27. Di Rienzo J, Guzmán AW, Casanoves F. A multiple-comparisons method based on the distribution of the root node distanceofabinarytree.JAgricBiolEnvironStat.2002;7(2):129-142.https://doi.org/10.1198/10857110260141193

28. Meza-Barreto G, Sanjuanelo-Corredor DW, Gallego-Marín MI. Molecular detection of bovine leukemia virus: a study in Colombia cluster. Revista Ciencia y Agricultura. 2016; 13(2):47-55. doi: https://doi.org/10.19053/01228420. v13.n2.2016.5552

29. Úsuga-Monroy C, Echeverry J, López-Herrera H. Molecular diagnosis of bovine leukemia virus in a population of Holstein cows, Colombia. Archivos de Zootecnia. 2015; 64(248):383-388. http://www.uco.es/organiza/servicios/ publica/az/php/img/web/11_1233 12 35981.pdf

30. Rodríguez-Neira CF, Viasús-Lemus AM. Determinación serológica de leucosis enzootica bovina mediante Elisa indirecta en vacas lecheras de Sotaquira. [Trabajo de grado]. Universidad Pedagógica y Tecnológica de Colombia: Tunja, Colombia; 2015. URL availaible in: https://www.academia.edu/16751928/Tesis_Leucosis_Angelica_y Cristian

31. Bautista RNA, Nova RYA, Pulido-Medellín MO, Andrade-Becerra RJ. Serological determination of enzootic bovine leukosis in raise heifers and adult cows of the Morichal path in Yopal, Casanare. Ciencia y Agricultura. 2013; 10(1):31-37. https://doi.org/10.19053/01228420.2832

32. Galvis-García T, Bautista-Amorocho H, Vásquez MC. Prevalence of antibodies against bovine viral diarrhea, bovine respiratory syncytial virus, infectious bovine rinotraqueitis, bovine leukosis, Neospora caninum, bovine parainfluenza (PI3) and paratuberculosis in cattle farms located in Aguachica and Rio de Oro, Cesar. Revista facultad de ciencias de la Salud UDES. 2016; 3(1):36. http://dx.doi.org/10.20320/rfcsudes.v3i1.s1.p022

33. Betancur H, Rodas GJ. Seroprevalece of bovine leukemia virus in animals with reproductive problems in Montería. Rev MVZ Córdoba. 2008; 13(1):1197-1204. https://doi.org/10.21897/rmvZ.411

34. Vega-Ahumada HJ, Barragán-Garnica LA. Prevalencia de leucosis viral bovina en ganado Holstein lechero en el municipio de Pacho Cundinamarca, Vereda El Hatillo mediante Elisa Indirecta. [Trabajo de grado]. Bogotá D.C. Colombia: Universidad de la Salle; 2015. URL available in: http://hdl.handle.net/10185/17919

35. Villegas V. Leucosis bovina enzoótica. [Trabajo de grado]. Bogotá D.C. Colombia: Universidad de la Salle; 2015. URL available in: http://repository.lasalle.edu.co/handle/10185/17577

36. Benavides BB, Cedeño QDA, Serrano dlCMF. Epidemiological study of bovine leukemia virus in dairy cows in six herds in the municipality of Pasto, Nariño. Rev Lasallista Investig. 2013; 10(1):18-26. URL available in: http:// repository.lasallista.edu.co:8080/ojs/index.php/rldi/article/view/420

37. Cadavid-Gutierrez LA. Impacto del virus de la leucosis bovina en la producción de leche. [Tesis de maestría]. Palmira, Colombia: Universidad Nacional de Colombia; 2012. URL available in: http://bdigital.unal.edu.co/9308/

38. Carrero RJL, Arévalo MF, Tarazona SA, Cepeda BM. Seroprevalence for bovine Leucosis by indirect Elisa technique in Clusters milkmen located in Mesa de los Santos, Santander. Revista Spei Domus. 2009; 5(11):6-11. URL available in: https://revistas.ucc.edu.co/index.php/sp/article/view/590

39. Camacho R, Carvajal LY, Castellanos-Dominguez YZ, Días WF, Vásquez MC. Presence of IgG antibodies against reproductive infections in breeding bulls of Magdalena Medio, Colombia. RCCP. 2015; 28(4): 323-330. doi: https:// doi.org/10.17533/udea.rccp.v28n4a04 
40. Trono KG, Pérez.Filgueira DM, Duffy S, Borca MV, Carrillo C. Seroprevalence of bovine leukemia virus in dairy cattle in Argentina: comparison of sensitivity and specificity of differents detection methods. Vet Microbiol. 2001; 83(3):235-248. https://www.ncbi.nlm.nih.gov/pubmed/11574172

41. Polat M, Takeshima S, Aida Y. Epidemiology and genetic diversity of bovine leukemia virus. Virol J. 2017; 14(209): 1-16. https://doi.org/10.1186/s12985-017-0876-4

42. Meas S, Ruas FJ, Usui T, Teraoka Y, Mulenga A, Chang KS, et al. Seroprevalence and molecular evidence for the presence of bovine immunodeficiency virus in Brazilian cattle. Jpn J Vet Res. 2002; 50(1):9-16. https://www.ncbi. nlm.nih.gov/pubmed/12201018

43. Nishiike M, Haoka M, Doi T, Kohda T, Mukamoto M. Development of a preliminary diagnostic measure for bovine leukosis in dairy cows using peripheal white blood cell and lymphocyte counts. J Vet Med Sci. 2016; 78(7):11451151. doi: https://doi.org/10.1292/jvms.16-0022

44. Lee E, Kim E, Ratthanophart J, Vitoonpong R, Kim B, Cho I, et al. Molecular epidemiological and serological studies of bovine leukemia virus (BLV) infection in Thailand cattle. Infect Genet Evol. 2016; 41:245-254. doi: https://doi. org/10.1016/j.meegid.2016.04.010

45. Meas S, Ohashi K, Tum S, Chhin M, Te K, Miura K, et al. Seroprevalence of bovine immunodeficiency virus and bovine leukemia virus in draught animals in Cambodia. J Vet Med Sci. 2000; 62(7):779-781. URL availaible in: https://www.ncbi.nlm.nih.gov/pubmed/10945301

46. Polat. , M. , Moe HH, Shimogiri T, Moe KK, Takeshima SN, et al. The molecular epidemiological study of bovine leukemia virus infection in Myanmar cattle. Arch Virol. 2017; 162(2):425-437. doi: https://doi.org/10.1007/ s00705-016-3118-y

47. Maresca C, Costarelli S, Dettori A, Felici A, Iscaro C, Feliziani F. Enzootic bovine leukosis: Report of eradication and surveillance measures in Italy over an 8-year period (2005-2012). Prev Vet Med. 2015; 119(3-4):222-226. doi: https://doi.org/10.1016/i.prevetmed.2015.02.024

48. Poeta P, Coelho AC, Rodrigues J. Epidemiological survey of enzootic bovine leukosis in Portugal from 1995 to 2005. Arq Bras Med Vet Zootec. 2008; 60(5):1250-1254. doi: https://doi.org/10.1590/S0102-09352008000500030

49. Kaura HT, Hübschle , O.J.. The occurrence of enzootic bovine leukosis (EBL) in Namibia- an epidemiological study. Dtsch Tierarztl Wochenschr. 1994; 101(2):66-67. URL availaible in: https://www.ncbi.nlm.nih.gov/ pubmed/8149904

50. Schoepf KC, Kapaga AM, Msami HM, Hyera JMK. Serological evidence of the occurrence of Enzootic Bovine Leukosis (EBL) virus infection in cattle in Tanzania. Trop Anim Health Prod. 1997; 29(1):15-19. URL availaible in: https:// www.ncbi.nlm.nih.gov/pubmed/9090010

51. Ghanem YM, Ahmed MS, Abdelkader AH. Prevalence of Enzootic Bovine Leukosis (EBL) in the Northern Somalia. Bull Anim Health Prod Afr. 2011; 59(2):190-198. URL availaible in: https://www.ajol.info/index.php/bahpa/ article/view/74419

52. Ndou RV, Sejesho F, Dzoma BM, Motsei LE, Nyirenda M, Bakunzi FR. A serosurvey of the prevalence of enzootic bovine leukosis in the Mafikeng area of the North West Province of South Africa. J Hum Ecol. 2011; 36(1):53-55. doi: https://doi.org/10.1080/09709274.2011.11906417

55. Hernández-Herrera DY, Posso-Terranova AM, Benavides JA, Muñoz-Flórez JE, Giovambattista G, Álvarez-Franco LA. Bovine Leukemia virus detection in Creole Colombian breeds using nested-PCR. Acta Agron. 2011; 60(4):312-318. URL availaible in: http://www.scielo.org.co/scielo.php?script=sci_arttext\&pid=S0120-28122011000400003

56. Erskine RJ, Barttlet PC, Byrem TM, Render TM, Febvay C, Houseman JT. Association between bovine leukemia virus, production, and population age in Michigan dairy herds. J Dairy Sci. 2012; 95(2):727-734. doi: https://doi. org/10.3168/jds.2011-4760

57. Felmer R, Zúñiga J, López A, Miranda H. Prevalence and space distribution of brucellosis, bovine leukaemia, bovine viral diarrhea and infectious bovine rhinotracheitis by using bulk milk ELISA test in dairy herds of the IX Region, Chile. Arch Med Vet. 2009; 41:17-16. doi: http://dx.doi.org/10.4067/S0301-732X2009000100003

58. Ghezzi PC, Dolcini GL, Gutiérrez SE, Bani PC, Torres JO, Arroyo GH, et al. Bovine leukemia virus (BLV): prevalence in the Cuenca Lechera Mar y Sierras from 1994 to 1995. Rev Argent Microbiol. 1997; 29(3):137-146. URL availaible in: https://www.ncbi.nlm.nih.gov/pubmed/9411488

59. Mohammadi V, Atyabi N, Brujeni GN, Ltfollahzadeh S, Mostafavi E. Seroprevalence of bovine leukemia virus in some dairy farms in Iran. Glob Vet. 2011; 7(3):305-309. URL availaible in: https://www.idosi.org/gv/GV7(3)11/17.pdf

60 Ochoa-Cruz A, Uribe A, Gutiérrez M. Estudio del potencial zoonótico del virus de la leucosis bovina y su presencia en casos de cáncer de seno. Univ Sci. 2006; 11(2):31-40. URL availaible in: https://revistas.javeriana.edu.co/index. $\mathrm{php} / \mathrm{scientarium/article/view/4968}$ 